\title{
Participatory Mode: A New Mode of Economic and Social Development Assistance in Tibet
}

\author{
Zeng-Yan XIAO \\ Department of History and Tourism, Zhaoqing University, Zhaoqing, China \\ email: 173877049@qq.com
}

\begin{abstract}
Keywords: Participatory mode, Counterpart assistance to Tibet, Economic and social development.
\end{abstract}

\begin{abstract}
The old mode of counterpart assistance to Tibet can not fully meet the new need of herdsman now. So, this paper put forward the achievements and drawbacks of old mode by using the correlation method to analyze the statistical yearbook data. Based on this, the paper gave a reason why introduced the "participatory" mode to aid work, built the new mode and analyzed the influence to the economic and social development of Tibet. Then, the paper draw the conclusion because the new mode focuses on the vulnerable group and aims to promote the herdsman's participation, then it can update their self-development ability and improve the effectiveness of aid work. So, it is best to use the "participatory" mode in the late stage of aid work, and it would be possible innovation to introduce the new mode to aid work in Tibet.
\end{abstract}

\section{Introduction}

Counterpart assistance to Tibet is the development assistance which aims to change the backward production outlook and promotes leapfrog development of Tibet. Counterpart assistance to Tibet has been made for 20 years. Under the support of the central government and through implementing talent technology assistance, economic assistance and project assistance to Tibet, the economic, social, cultural, ecological construction have made remarkable results. However, the drawbacks of the old mode gradually appear. From a macro perspective, it showed that the herdsman can't fully participate and share the economic development achievement in Tibet. From a micro perspective, it still has a gap between the supply and demand of counterpart assistance.

"Participatory" mode is the new mode of the development. So, introducing "participatory" to counterpart assistance to Tibet, not only can improve the drawbacks, but also can aim to the goal of "farmers". Hence, "empowerment" and "participation" can realize the object of development and advocate the conscience of the interaction, meet the demand of herdsmen and improve their self-development ability. Only by meeting the needs of the vast majority of farmers and herdsmen group, can it truly reflects the effectiveness of the assistance to Tibet and achieved the basic goal of counterpart Tibet. So it really answers the fundamental question of "why aid, aid for whom".

The paper is organized as follows. Section two outlines the achievement and drawbacks of the old mode. Section three analyzes the reason why introduce the participatory mode. Section four describes what's the participatory counterpart assistance to Tibet. Section five presents the economic and social influence of the new mode, and the final Section offers the conclusions.

\section{The Achievements and Drawbacks of Old Aid Mode}

\section{The Achievements.}

Since the third work symposium of Tibet, the central government orders the 14 developed provinces to counterpart aid 7 Tibetan districts hand by hand. After 20 years, these provinces have input much manpower and material to support the construction of Tibet(see Table 1). According to Solow model and Total production function, $\mathrm{Y}=\mathrm{A} \cdot \mathrm{F}(\mathrm{K}, \mathrm{L}, \mathrm{R})$, the growth factors includes the labor, capital, technology and natural resource. We think, almost in the 20 years of counterpart assistance to Tibet, the technology aid have promoted the A(technology) foctor, the fund and project aid have 
promoted the K(capital) foctor, the education and medical aid have promoted the L(labor) foctor, and the industry and talent aid have promoted the R(natural resource)foctor, then to promote the Y( total yield) to grow a lot. From the statistical yearbook, we can clearly see the GDP grows from \$ 4.6 billion in 1994 to \$ 102 billion in 2014 which is almost 22 times as before, and the production of GDP and average GDP are on the uptrend too. Based on the statistical data, we analyze the correlation between the GDP and the index which influenced by the counterpart assistance to Tibet (see Table 2).

Table 1 The achievements of counterpart assistance in 20 years(1994-2014)

\begin{tabular}{|c|c|c|c|c|}
\hline $\begin{array}{l}\text { Recipient } \\
\text { region }\end{array}$ & $\begin{array}{l}\text { Aid } \\
\text { province }\end{array}$ & $\begin{array}{l}\text { Sent cadres } \\
\text { (person) }\end{array}$ & $\begin{array}{l}\text { Aid funds } \\
\text { (billion yuan) }\end{array}$ & $\begin{array}{l}\text { construction } \\
\text { projects(unit) }\end{array}$ \\
\hline \multirow[t]{2}{*}{ Lhasa } & Beijing & 413 & 2.8 & 200 \\
\hline & Jiangsu & 408 & 2.76 & 786 \\
\hline \multirow[t]{4}{*}{ Shigatse } & Shanghai & 376 & 2.634 & 1216 \\
\hline & Shandong & 383 & 2.642 & 979 \\
\hline & Jilin & 149 & 0.475 & 193 \\
\hline & Heilongjiang & 148 & 0.463 & 223 \\
\hline \multirow{3}{*}{$\begin{array}{l}\text { Shannan } \\
\text { area }\end{array}$} & Hunan & 307 & 1.1 & 308 \\
\hline & Hubei & 321 & 1.34 & 410 \\
\hline & Anhui & 109 & 0.9 & 165 \\
\hline \multirow{2}{*}{$\begin{array}{l}\text { Nyingchi } \\
\text { area }\end{array}$} & Guangdong & 278 & 3.46 & 943 \\
\hline & Fujian & 295 & 1.7 & 700 \\
\hline \multirow[t]{2}{*}{ Qamdo area } & Tianjin & 325 & 0.8 & 113 \\
\hline & Chongqing & 99 & 0.68 & 154 \\
\hline \multirow[t]{2}{*}{ Nagqu area } & Zhejiang & 340 & 2 & 540 \\
\hline & Liaoning & 336 & 0.66 & 361 \\
\hline \multirow[t]{2}{*}{ Ali area } & Hebei & 220 & 0.66 & 179 \\
\hline & Shanxi & 221 & 0.927 & 160 \\
\hline
\end{tabular}

Table 2 The correlation between GDP and index of counterpart assistance to Tibet

\begin{tabular}{|l|l|l|l|}
\hline number & Index & $\begin{array}{l}\text { Correlation } \\
\text { coefficient }\end{array}$ & $\begin{array}{l}\text { Statistical } \\
\text { significance level }\end{array}$ \\
\hline 1 & Gross Output Value of Animal Husbandry & $0.981^{* *}$ & 0.000 \\
\hline 2 & $\begin{array}{l}\text { Per Capital Annual Net Income of Rural } \\
\text { Households }\end{array}$ & $0.998^{* *}$ & 0.000 \\
\hline 3 & Gross Output Value of Primary Industry & $0.987^{* *}$ & 0.000 \\
\hline 4 & $\begin{array}{l}\text { Gross Output Value of Secondary } \\
\text { Industry }\end{array}$ & $0.995^{* *}$ & 0.000 \\
\hline 5 & Gross Output Value of Tertiary Industry & $0.999^{* *}$ & 0.000 \\
\hline 6 & $\begin{array}{l}\text { College students number of per 10000 } \\
\text { Population }\end{array}$ & $0.721^{* *}$ & 0.002 \\
\hline 7 & Every Thousand People has Berths to Count & $0.963^{* *}$ & 0.000 \\
\hline 8 & $\begin{array}{l}\text { Number of Medical Technical Personnel Per } \\
1000 \text { Population }\end{array}$ & $0.846^{* *}$ & 0.000 \\
\hline 9 & Number of Agriculture Personnel & $0.954^{* *}$ & 0.000 \\
\hline 10 & Aid Funds & $0.928^{* *}$ & 0.001 \\
\hline
\end{tabular}

\section{The Drawbacks.}

From Table 3, we can see the annual per capital income of rural households in Tibet has the rising trend year by year. However, compared with the urban household's in Tibet, even with the same 
national lever, it is still a large gap between them. Hence, it shows that urban and rural differences are still evident, and the herdsman(rural household)still can not fully share the fruits of the economic and social development of counterpart assistance to Tibet.

Table 3 The rural and urban household income in Tibet and the national lever

\begin{tabular}{|l|l|l|l|}
\hline Year & $\begin{array}{l}\text { Annual Per Capital } \\
\text { Disposable Income of } \\
\text { Rural Households of the } \\
\text { Nation(yuan) }\end{array}$ & $\begin{array}{l}\text { Annual Per Capital } \\
\text { Income of Rural } \\
\text { Households in } \\
\text { Tibet(yuan) }\end{array}$ & $\begin{array}{l}\text { Annual Per Capital } \\
\text { Disposable Income of } \\
\text { Urban Households in } \\
\text { Tibet(yuan) }\end{array}$ \\
\hline 1994 & 1220 & 817 & 3330 \\
\hline 2000 & 2253 & 1331 & 6448 \\
\hline 2005 & 3255 & 2078 & 8411 \\
\hline 2010 & 5919 & 4139 & 14980 \\
\hline 2011 & 6977 & 4904 & 16196 \\
\hline 2012 & 7917 & 5719 & 18028 \\
\hline 2013 & 8896 & 6578 & 20023 \\
\hline 2014 & 10489 & 7359 & 22016 \\
\hline 2015 & 11422 & 8244 & 25457 \\
\hline
\end{tabular}

In the old mode of counterpart assistance to Tibet, the aid provinces always supply the funds and projects that based on the administrative order and superior policy document, instead of thinking more about the herdsman's real need. Therefore, because of different interests, it is difficult to avoid deviations of the supply and demand between the donors and recipients. Especially in recent years, the aid funds are tight but the herdsman increases the need, so the supply and demand gap gradually widened. In addition, there are still a lot of deviations, such as ignoring the vast majority of herdsman's demand, paying attention to urban construction but ignoring rural construction, paying attention to construction but ignoring maintaining the projects. So, herdsmen can not fully participate in the project construction.

\section{The Reason Why Introduce the Participatory Mode}

Firstly, relevant policies have changed. The Fifth Tibet Work Symposium put forward the new policy that the aid funds and projects must be tilted to the herdsmen and pastoral areas. By doing so, it can ease the old mode's drawbacks that paying attention to urban construction but ignoring rural construction. In addition, the pattern of counterpart assistance to Tibet has changed a lot. For example, the central government ordered to change the Transfusion pattern to the Hematopoietic pattern, which is aimed at promoting the herdsman's livelihood ability by skills training, project construction, market guidance, etc. Thus, it not only can aid the herdsman by supporting construction funds, but can help them self-development and creation.

Secondly, the herdsman's sense and ability of participation has gradually upgraded. Thus, their need and demand to the assistance work has also gradually changed. However, the aid method and ideas of some province can not keep pace with the times. It can not be avoided to cause a conflict between the aid province and the herdsman. At the same time, we also can see some aid provinces have aware of the changes and begin to reflect the way of assistance, such as beginning to emphasis the participation of herdsman, beginning to title the funds to the herdsman and focus on the herdsman's need and interest. All this have showed that there was a spark of thought and idea of participatory mode in current assistance work.

Thirdly, the "participatory" mode is the currently popular and feasible aid mode. As described above, introducing "participatory" mode to aid work can change the drawbacks of old mode, and can turn the development goals from the city construction to the herdsman's self-development and focus on their need. By doing so, it can help the herdsman to benefit from the assistance project and fully enjoy the achievement of counterpart assistance to Tibet. The "participatory" mode advocates 
Down-Top mechanism to convey the herdsman's need and demand to the superior government, and it respects the herdsman's will of participation in project construction. Also it actively listens to the herdsman's voice and promote communication between the two sides of aid work. So, it can build the items that the herdsman really wants, then eases the conflict, saves the funds and increases the aid work's efficiency. Moreover, the "participatory" mode also advocates the empowerment to encourage them to participate and make decision in construction, to make them aware of the master consciousness. Hence, the "participatory" mode can change the mode from passive to active and correct the deviation in time.

Finally, participatory development mode has become a mainstream development mode which driven by the World Bank in 1990s, and it has a set of unique methods and tools. For example, Bengali Rural Bank's Small loan model focus on the poor people and advocates the idea of self-hiring. These claims are reflected the ideas of participatory development and gives us a successful case for reference of poverty alleviation work around the world. In addition, the participatory development mode has practiced in West Africa and in the poverty areas of China, such as YunNan province, SiChuang province and GuiZhou province. Especially in 2001, the State Council of China pushes forward the participatory poverty alleviation with the support of the Ford Foundation. All those practice provide a solid foundation to the application of participatory counterpart assistance to Tibet.

\section{The Concept and Idea of Participatory Counterpart Assistance to Tibet}

Participatory counterpart assistance to Tibet refers to introduce participatory development concept to aid work, and aims for letting most herdsman participating and supervising the whole process of aid work. Also, it encourages the herdsman to express the interest by using Down-Top mechanism and basing on the local knowledge and resources. In a word, the participatory counterpart assistance to Tibet is the new mode of aid work that aims for promoting the herdsman's ability of self-development and decision making.

Participatory counterpart assistance to Tibet uses the participatory methods and tools to do the field research, in order to understand the need of herdsman and diagnose problems. Then it can ease the old mode's drawback of excluding the herdsman in the project establishment process. The new mode consists of five parts, such as livelihood frame, governance frame, PRA(participatory Rural Appraisal) tool frame, method frame, conflict management frame and action frame. The Livelihood Frame includes the material capital, natural capital, financial capital, human capital and social capital. The livelihood frame can fully understand the herdsman's livelihood, then to provide the support target. The Governance Frame consists of the empower mechanism, participatory mechanism, making target groups benefit mechanism, interest expression and pluralistic communication mechanism. These mechanism all pay attention to the vulnerable groups and capacity building of herdsmen. The PRA Tool Frame are comprised with interview tools, analyzing tools, sorting tools, illustration tools and meeting tools. The Method Frame includes the related interest group analysis method, Basing on local knowledge and information methods, participatory village planning. The Conflict Management Frame mainly includes the analysis, prediction and management of conflict. The Action Frame orders the participatory action should follow the procedure of preparing, confirming the problem, picking the PRA tool, selecting the plan, acting-evaluating and spread the result.

\section{The Influence of Participatory Mode Gives to Economic and Social Development in Tibet}

Introducing the participatory mode to counterpart assistance to Tibet maybe gives the influence the economic and social development in Tibet as follows.

Firstly, in a micro perspective, participatory counterpart assistance can resolve the problem of supply and demand gap of aid projects, then to ease the conflict because of the gap. Only the two side of counterpart assistance actively participate, that is to say, the herdsmen actively apply and suggest to the projects and the governments actively investigate the herdsman's demand, can it well 
done the aid work. Thus, it not only can meet the herdsman's demand, but also can use the funds on the blade, and save the country's funds.

Secondly, from these statistics(see table 3), we think that it is necessary to continue to increase the income of herdsmen, and to reduce the income gap among herdsman, urban residents in Tibet and the nation, so that to make the herdsmen benefit from the project and improve the effectiveness of counterpart assistance to Tibet.

Thirdly, in the social sphere, the participatory development aims for the fair and making the target group benefited in the social life. Since the nature of the counterpart assistance to Tibet is to develop the people, it should respect the herdsman that accounting for the vast majority of the Tibetan people. "Participatory" is the new development concept, which stresses on the "empower", "participate" and aims at vulnerable groups. From the Tibetan economic development point of view, the vulnerable group refers to the herdsman. That is to say, we should respect the herdsman's participatory right and guarantee the herdsman be benefited from the political and economic interests. By doing so, it can make the herdsman being the main body and really participate in the development construction. Then, it can promote the sustainable development of the economy in Tibet.

Finally, in the economic sphere, the participatory development advocates to carry out long-term and comprehensive study of development costs and efficiency. Because the participatory mode emphasis on the participation of the target group, it will reduce the possibility of deviation occurred when all stakeholders involved and consulted in the project construction. Hence, it will improve efficiency of construction and save the funds, then carry out with high efficiency. Although the consultation and negotiation will pay a certain amount of time, it is still negligible when compared to the entire project construction funds. In addition, due to the stakeholders' compromise, consultation and cooperation, it can develop a maximum benefit of the program and inevitably promote the efficient implementation of the project. Therefore, in the long run, "participatory" can promote the effective construction of the target group's capacity building and ensure the effective allocation of funds in Tibet. So, on the whole, it is effective and low cost.

\section{Summary and Conclusions}

Our analysis has used a new development aid mode to Tibet, which can give a new perspective to the counterpart assistance work and suggestions to the local government to deal with the problems between the herdsman and government. Through the study of this article, we can draw the following conclusions: introducing the "participatory" mode to assistance work embodies the essence of "development", also it is the better way to enhance the effectiveness. "Participatory" intervention could reflect and express the interests of herdsman and aim to meet their needs. So it can reduce the supply and demand's gap, save the money and enhance the effectiveness of assistance to Tibet, and promote economic and social development.

In this paper, we argue, participatory assistance is the best way for assistance to Tibet in later period. However, the application of participatory assistance to Tibet will face a series of problems, Such as the problems of government's ideas, characters and action conversion, the problems of herdsman's participation and decision-making ability, the problems of participatory mode's, and so on. Thus, we should not only adhere to the government's principal status to mobilize resources rationally and to dredge transfer channels, but also reasonably use participatory development idea and tool, and continue to improve the defect of the aid work.

\section{References}

[1]Xiang-Song YE, Tian-Jian LONG, Macroeconomics. Northeast university of finance and economics Press, Dalian, 2010, PP. 213-214.

[2]Ming-Hong YANG, The theorical understanding and achieved path research on the counterpart assistance's effectiveness, Chinese Tibetology, 3(2014)127-129. 
[3]Dai-Yuan WANG. The Study on the economic and social benefits of counterpart assistance work in Tibet, Tibetan Ancient Books Press, Lhasa, 2012, pp. 222.

[4]Xiao-Liu YANG, Paticipatory action: the development study on the Yi people of Liangshan county, National Publishing House, Beijing, 2008, PP.40-48.

[5]xiao-Yun LI, The introduction of normal development, The Social Science Press, Beijing, 2012, pp.121-134.

[6]Jiu-Yan PAN. The economic analysis of national assistance to Tibet. Sichuan University Press, Chengdu, 2009, pp.45-70.

[7] L. Chambers, Rural development: putting the last first, Longman Press, London,1983.

[8]David H Lumsdaine, Moral vision in international politics: the foreign aid regime, 1949-1989, Princeton University Press, Princeton, N.J, 1993.

[9]Helmut Führer, The story of official development assistance. Organization for economic co-operation and development, Paris, 1996.

[10]Melvyn C. Goldstein, Development and change in rural Tibet, Asian Survey, 43(2003)758-779. 